URL: https://unesdoc.unesco.org/ark:/48223/pf0000 048063/PDF/074816engo.pdf.multi.nameddest $=4806$ 3 (data zvernennya: 17.01.2020) [in English].
37. Vasak, K. (1984) Pour une troisieme generation des droits de l'homme // Studies and Essays on International Humanitarian Law and Red Cross Principles / Ed. by C. Swinarski. Hague [in French].

Мірошніченко С.B. кандидат історичних наук, доцент кафедри всесвітньої історії Харківського національного педагогічного університету імені Г.С. Сковороди https://orcid.org/0000-0002-9384-7491

\title{
АЛГОРИТМ УПРОВАДЖЕННЯ ДИСТАНЦЙНОГО НАВЧАННЯ ПРИ ВИКЛАДАННІ КУРСУ «ІСТОРІЯ СТАРОДАВНІХ ГРЕЦІЇ ТА РИМУ»
}

У статті визначено законодавчу базу регламентації дистанційного навчання в Україні, його переваги та основні елементи, коло авторів, алгоритм та основні аспекти впровадження курсу «Історія Стародавніх Греції та Риму» в навчальний прочес із використанням як окремих сервісів, які надають комплексне забезпечення навчального прочесу, та і допоміжних задля залучення максимальної кількості стандартних онлайн та офлайн сервісів для більш ефективної організації навчального прочесу, зокрема, і платформи Mоодle. Сформульовані принщипи впровадження курсу на цій платформі, його елементи та змістове наповнення, визначені переваги та недоліки його використання як під час навчальних занять, так і під час впровадження його як елементу самостійної роботи, а також описаний алгоритм проведення іспиту в дистанційному форматі.

Ключові слова: дистаниійне навчання, Moodle, сервіси Google, Zoom, LearningApps.

In the article the legislative base of regulation of the controlled from distance studies is certain in Ukraine, his advantages and basic elements, circle of authors, algorithm and basic aspects of introduction of course "History of Ancient to Greece and Rome» in an educational process with the use as separate services that give the complex providing of educational process, and auxiliary for the sake of bringing in of maximal amount of standard online and of лайн services for more effective organization of educational process, in particular, and platform Moodle. The set forth principles of introduction of course are on this platform, his elements and rich in content filling, certain advantages and lacks of his use both during lessons and introduction of him as element of independent work, and also the described algorithm of realization of examination in distance.

Keywords: distance education, Moodle, Google services, Zoom, LearningApps.

Постановка проблеми. На сучасному етапі інноваційна діяльність $є$ обов'язковим елементом для будь-якої професійної діяльності. У навчальному процесі це перш за все реалізується у теоретичній розробці й практичному втіленні нових підходів і алгоритмів у мету, зміст, методи і форми взаємодії здобувача освіти та його викладачів.

Одним із видів інновацій в організації професійної освіти є введення дистанційного навчання.

Через поширення вірусу Covid-19 із березня 2020 року всі країни почали запроваджувати карантинні заходи, що призвело до закриття на невизначений час усіх навчальних закладів. Вони змушені були за короткий термін перейти на дистанційний навчальний процес. Після послаблення карантину у світі стало зрозуміло, що людст- во перейшло на нову стадію розвитку, де дистанційне навчання буде відігравати велику, якщо не визначальну, роль.

В Україні дистанційна освіта ще в 2000 р. була затверджена Концепцію розвитку дистанційної освіти в Україні, в якій було обгрунтовано доцільність, мету, основні завдання та очікувані наслідки створення і впровадження такої системи [Концепція розвитку 2000]. У 2013 р. вийшло уточнене й конкретизоване «Положення про дистанційне навчання», в якому деталізовано науково-методичне забезпечення й особливості організації навчального процесу 3 використанням технологій дистанційного навчання.

Наразі процес дистанційної освіти регламентується в основному Законом України про освіту, Положенням про дистанцій- 
не навчання, i, відповідно Положенням про дистанційну освіту у конкретному закладі вищої освіти, а також Методичними рекомендаціями щодо організації дистанційного навчання в Україні МОН України 2020 р.

На відміну від заочного навчання, дистанційне навчання (далі - ДО) дає можливість вчитися, перебуваючи на будь-якій відстані від навчального закладу. Серед переваг ДО відзначимо такі:

- відбувається взаємодія викладача та здобувача у віртуальному просторі;

- здобувачам надається можливість самостійної роботи 3 навчальними матеріалами, а також у процесі навчання;

- передбачає мінімальні витрати 3 бюджету;

- втілює концепції мобільних ідей, знань і навчання за допомогою обміну освітніми ресурсами;

- передбачає одночасне навчання значної кількості людей;

- підвищує якість навчання за рахунок застосування сучасних засобів, об'ємних електронних бібліотек та інше;

- сприяє створенню єдиного освітнього середовища (що $є$ особливо актуальним для корпоративного навчання).

Під час дистанційного навчання використовуються такі основні елементи:дистанційні курси; веб-сторінки й сайти; електронна пошта; форуми й блоги; чат i ICQ; теле- і відеоконференції; віртуальні класні кімнати та інше.

Аналіз актуальних досліджень. Аналіз джерел $з$ даного питання засвідчує значний інтерес вітчизняних та зарубіжних науковців до проблем розвитку сучасної освіти. Дистанційна система навчання перебуває в центрі уваги наукових кіл, і сучасні тенденції свідчать про подальшу активізацію досліджень у цій сфері. Зокрема, теоретичними, методологічними та методичними проблемами дистанційного навчання займалися такі науковці, як О. Андрєєв, В. Биков, С. Вітвицька, Б. Гершунський, Р. Гуревич, М. Жалдак, Ю. Жук, М. Кадемія, В. Кухаренко, Г. Козлакова, І. Козубовська, Є. Машбиць, Д. Опеншоу, А. Петров, Є. Полат, І. Підласий, П. Стефаненко, Н. Тверезовська, О. Тищенко, А. Хуторський, І. Хорев, В. Ясулайтіс [Адамова 2012;
Кухаренко 2018; Муковіз 2016; Радкевич 2020].

Мета статті: визначити законодавчу базу регламентації дистанційного навчання в Україні, його переваги та основні елементи, коло авторів, алгоритм та основні аспекти впровадження, сформулювати принципи впровадження курсу «Історія стародавніх Греції та Риму» на цій платформі, його елементи та змістовне наповнення,переваги та недоліки його використання як під час навчальних занять, так і впровадження його як елементу самостійної роботи, а також описаний алгоритм проведення іспиту в дистанційному форматі.

Виклад основного матеріалу. До останнього часу в Україні дистанційне навчання радше застосовувалося в окремих дистанційних курсах, які забезпечували комплексне навчання певного предмета. I3 12 березня 2020 р. в Україні запроваджено карантин із подальшим переходом на дистанційне навчання для всіх закладів освіти.

Розглянемо алгоритм впровадження дистанційної освіти на історичному фа культеті ХНПУ імені Г.С. Сковороди на прикладі курсу «Історія стародавніх Греції та Риму».

Перед початком курсу здобувачам обов'язково надаються рекомендації щодо використання ресурсів, послідовності виконання завдань, особливостей контролю тощо. Бажано також урахувати універсальність цих інструментів, щоб скоротити кількість різних платформ, які використовуються для навчання.

Порівнюючи кілька інструментів, варто враховувати зрозумілість інтерфейсу для здобувачів. Перевагу краще надати україномовним ресурсам або таким, що мають інтуїтивно зрозумілий інтерфейс.

Під час занять можливе використання як окремих сервісів, які надають комплексне забезпечення навчального процесу, та і допоміжних задля залучення максимальної кількості стандартних онлайн та офлайн сервісів для ефективної організації навчального процесу. Серед таких необхідно відзначити, перш за все, можливості платформи Zoom i GoogleClassroom, у використанні яких наявні свої позитивні моменти і певні обмеження. 
Платформа GoogleClassroome сервіcoм, що пов'язує GoogleDocs, GoogleDrive i Gmail, та дозволяє організувати онлайннавчання, використовуючи відео-, текстову та графічну інформацію. Основним елементом GoogleClassroom є групи. Функціонально групи нагадують структурою форуми, оскільки вони дозволяють здобувачам легко відправляти повідомлення іншим користувачам. Завдяки сервісу для спілкування Hangouts здобувачі й викладач мають змогу вести онлайн-бесіди в режимі реального часу з комп'ютера або мобільного пристрою, учасники можуть показувати свої екрани, дивитись і працювати разом над завданням. Також платформа дозволяє за допомогою Google-форм збирати відповіді здобувачів і потім проводити автоматичне оцінювання результатів тестування. Однак обмеженням ресурсу стало відсутність чату для безпосереднього спілкування.

Усі матеріали для підготовки автоматично передаються на Google-диск. У стрічці можна і потрібно коментувати завдання, відправляти завдання відразу можна декільком викладачам по декільком курсам. Можна відразу створити копії завдань всім студентам курсу, налаштовувати час публікації завдань, а також створювати Google таблиці з оцінками.

Свою ефективність показали й інструменти Google: вебінарний сервіс Google Meet (який не мав часових обмежень, на відміну від сервісу Zoom), сервіс проведення масових онлайн опитувань GoogleForms, поштовий сервіс GoogleMail у поєднанні 3 файловим сховищем GoogleDrive (зручно пересилати великі за обсягом матеріали для тих, хто не зміг приєднатися до предмету на платформі) та відео-хостинг YouTube для масових відкритих трансляцій записаних відео.

Zoom - це сервіс для проведення відеоконференцій та онлайн-зустрічей. Для цього потрібно створити обліковий запис. Користувачі можуть використовувати додаток як на комп'ютері, так і на планшеті чи смартфоні. Заняття можна запланувати заздалегідь, а також зробити посилання для постійних зустрічей у певний час. У платформу вбудована інтерактивна дошка, яку можна демонструвати здобувачам. Крім то- го, є можливість легко й швидко перемикатися 3 демонстрації екрана на інтерактивну дошку. Zoom - це широка аудиторія, демонстрація презентацій, фото і відео і, звичайно, можливість бачити співрозмовника, що важливо під час проведення семінарського заняття.

LearningApps.org - онлайн-сервіс, що дозволяє створювати інтерактивні вправи. Ïх можна використовувати в роботі 3 інтерактивною дошкою або як індивідуальні вправи для здобувачів. Дозволяє створювати вправи різних типів на різні теми. Конструктор LearningApps.org призначений для розробки, зберігання та використання інтерактивних завдань. Тут можна створювати вправи для використання 3 інтерактивною дошкою, наприклад: знайти співвідношення між портретом і особою, твором ї його автором, терміном і його визначенням тощо.

Навчання в Харківському національному педагогічному університеті імені Г.С. Сковороди наразі здійснюється за допомогою платформи дистанційної освіти (далі ПДО) Moodle та допоміжних сервісів Google.

Це безкоштовна відкрита система управління дистанційним навчанням, яка дозволяє використовувати широкий набір інструментів для освітньої взаємодії «викладач - здобувач - адміністрація 3ВО». Зокрема, вона надає можливість подавати навчальний матеріал у різних форматах (текст, презентація, відеоматеріал, вебсторінка; лекція-семінар як сукупність вебсторінок із можливим проміжним виконанням тестових завдань); здійснювати тестування та опитування 3 використанням питань закритого (множинний вибір правильної відповіді та зіставлення) і відкритого типів; здобувачі можуть виконувати завдання з можливістю пересилати відповідні файли. Крім того, система має широкий спектр інструментів моніторингу навчальної діяльності, наприклад: щодо загального часу роботи здобувачів 3 конкретною навчальною дисципліною, відповідними темами або складниками навчального матеріалу, загальної успішності здобувача або групи в процесі виконання тестових завдань тощо. 
Співпраця викладача зі здобувачами відбувається за допомогою двох типів модулів: «Види діяльності» та «Ресурси». Перша група модулів - «Види діяльності» передбачає можливість створення завдань для оцінювання здобувачів. Ці об'єкти надають можливості для спілкування зі здобувачами (наприклад, об'єкти «Форум», «Чат», «Зворотній зв’язок»), їхнього тестування (модуль «Тести»), виконання завдань, що передбачають завантаження файлів із результатами роботи (наприклад, модулі «завдання» чи «семінар»), розміщення елементів для спільної роботи (модуль «Вікі»). Pecypc у системі Moodle - це група об'єктів, які дозволяють додати до курсу будьякий вміст. Наприклад, це можуть бути вебсторінки, текстові сторінки, написи, посилання на файли (модуль «Файл»), вебсторінки (модуль «URL-веб посилання»), каталог із файлами (модуль «Тека»), текстові сторінки у форматі книги (модуль «Книга»).

В інтегрованій навчальній дисципліні «Історія Стародавніх Греції та Риму і Стародавнього Сходу» розглядаються основні етапи становлення та розвитку людського суспільства 3 моменту його виникнення до створення стратифікованих суспільств, розвиток цивілізацій Сходу, Стародавніх Греції та Риму як в цілому, так і окремих частин, при чому особливу увагу приділено політико-географічним утворенням, що відіграли значну роль у іiі розвитку (Сгипет, держави Межиріччя, Китай, Індія, згодом Афіни, Спарта, грецькі колонії Північного Причорномор'я та інші).

Метою викладання навчальної дисципліни «Історія Стародавніх Греції та Риму і Стародавнього Сходу» $є$ аналіз трансформації людського суспільства, основних тенденцій і подій розвитку світу від появи перших державних утворень на Сході до припинення існування античної цивілізації внаслідок загибелі Західної Римської імперії.

Основними завданнями вивчення модулю №2 дисципліни «Історія Стародавніх Греції та Риму» є: 1) виявлення особливостей полісної системи Стародавньої Греції і Стародавнього Риму, виокремлення схожості та відмінності цієї системи у різних полісах Стародавньої Греції та особливос- тях полісної системи, яка існувала в Римській Республіці; 2) засвоєння поняття «антична форма власності», «повноправний громадянин полісу», «раб», виявлення різниці в їх становищі і їх місці в цій системі; 3) аналіз кризових явищ Стародавньої Греції та Стародавнього Риму, які привели до появи монархічної влади; 4) визначення місця давньосхідних і античних цивілізацій у всесвітній історії, їхнього внеску до розвитку культури людства.

Таким чином, виходячи 3 мети та завдання навчальної дисципліни, у модулі №2 «Історія Стародавніх Греції та Риму» розміщено такі елементи: алгоритм курсу, новини курсу, календар, тест, завдання, семінар, лекція, форум, чат, зворотній зв'язок, анкета, журнал оцінок 3 дисципліни, URLвеб посилання.

Зупинимось на детальному розгляді кожного $з$ них.

Модуль «Алгоритм курсу» містить відомості про основні види навчальної діяльності, що повинні виконувати здобувачі, навчаючись на курсі, дані про максимальну кількість балів за кожен вид діяльності, умови проведення модульного і підсумкового контролів, про загальну кількість годин згідно навчального плану та напряму підготовки, а також кількість годин лекційних і практичних занять, самостійних робіт, форму підсумкового контролю з курсу, а також містить список літератури та джерел, посилання на Internet ресурси, що використовуються при вивченні курсу.

Ресурс «Новини курсу» реалізовано у вигляді форуму, де здобувачі можуть задавати питання стосовно навчального процесу та структури курсу.

Ресурс «Календар» містить відомості про дату початку та завершення навчання на курсі, дату початку модулів, дату проведення підсумкового контролю, посилання на GoogleMeet конференцію.

Модуль «Тест» надає можливість створювати набори тестових завдань, дозволяє швидко перевіряти результати одразу багатьох здобувачів, оскільки їх відповіді перевіряються автоматично та одразу вносяться в журнал оцінок (основні затрати часу пов'язані з розробкою питань та наповненням ними «Банку запитань», налашту- 
ванням тесту). Цей модуль надає можливість розробляти тести, які можуть містити питання різних типів, а саме: множинний вибір, есе, перетягування в тексті, коротка відповідь, числова відповідь, відповідність встановлення відповідності, правильнонеправильно - $є$ лише два варіанти відповіді на питання «правильно» чи «неправильно».

URL модуль дозволяє забезпечити веб-посилання як ресурс курсу, використовуючи все, що знаходиться у вільному доступі в Інтернеті (на прикладі курсу посилання на репозиторій ХНПУ, відео 3 мережі YouTube та інші).

Ресурс «Файл» дозволяє надати файл у вигляді ресурсу курсу, файли розміщено у форматі PDF, в іншому випадку здобувачу буде запропоновано завантажити його.

Цей модуль використаний для того, щоб:завантажити презентації, надати алгоритм курсу, завантажити додаткові файли (наприклад, контурні карти), де здобувачі редагують їх на своєму ПК та подають їх для оцінювання.

Ресурс «Завдання» надає можливість ставити завдання, що вимагають від здобувачів відповіді в електронній формі (у будьякому форматі) і завантажити його на сервер.

Приклад:

\section{Рівень 1}

1. На якому півострові розташована Греція? а) Апеннінському; б) Індостан; в) Балканському; г) Мала Азія.

2. Що означає термін «ичивілізація»?

а) процес розвитку людства;

б) матеріальні залишки діяльності людей, щуо збереглися до нашого часу;

в) рівень розвитку суспільства, його матеріальної та духовної культури;

г) спільність археологічних пам'яток певного часу, щио відрізняються місиевими особливостями та перебувають на певній території.

3. У якому рочі засновано Рим?

a) y 1 рочі до н.е.;

б) у 682 роичі до н.е.;

в) y 753 ройі до н.е.;

2) y 836 рочі до н.е.

Рівень 2

1. Охарактеризуйте географічне положення $i$ природні умови Балканської Греції та Егейського басейну. Населення.

2. Проаналізуйте становище Римської імперї наприкінці $I V$-V cm. н. е. та основні напрями політика наступників Костянтина і їх боротьбу за самодержавство.

3. Відокремте основні особливості розвитку скульптури в Греції архаӥчного, класичного $i$ елліністичного періодів.

Виконане завдання здобувач надсилає у форматі одного чи кількох файлів в асинхронному режимі, чи режимі online, у тому числі з прикріпленими файлами. Якщо відповідь на завдання надіслана здобувачем для перевірки, то отримуємо сповіщення через електронну пошту про прибуття файлу з виконаним завданням.

Ресурс «Семінар» - це вид заняття, який надає можливість не тільки виконувати власну роботу, а й оцінювати результати роботи інших слухачів курсу. Наприклад, проходження тестового завдання за темою «Культура Стародавньої Греції» або «Стародавнього Риму».

Тест №7 «Соціально-економічний розвиток Італії в VI-III ст. до н. е.» є навчальним, у здобувачів $є$ можливість подивитися правильні відповіді, або тест №4 «Пелопоннеські війни» $\epsilon$ контрольним, здобувачам повідомляється тільки оцінка.

У тесті 1, 2, 3, 5, 6, 8 здобувачам надана можливість проходити тест кілька разів, при цьому кожна спроба автоматично оцінюється. Враховується краща спроба. Тести дають можливість виконувати статистичне опрацювання результатів тестування i експортувати їх у зовнішні файли для ведення журналу обліку успішності академічної групи.

Ресурс «Лекція» будується за принципом чергування сторінок із теоретичним матеріалом і сторінок з навчальними тестовими завданнями й питаннями. Послідовність переходів зі сторінки на сторінку заздалегідь визначається і залежить від того, як здобувач відповідає на запитання. На неправильні відповіді надається свій відповідний коментар. Базуючись на відповідях здобувача, система пересилає його на наступні сторінки або повертає на попередні сторінки для більш грунтовного вивчення.

Ресурс «Форум» використовується для організації дискусії з початку курсу. Наприклад, «Сильні і слабкі сторони афінської демократії». Після створення теми кожен учасник дискусії має змогу додати до неї свої відповіді або прокоментувати вже ная- 
вні. Це особливо зручно для нових членів групи, для швидкого освоєння основних завдань, над якими працює група. Історія обговорення цих проблем зберігається в базі даних. Користувач також може зіграти й більш активну роль в обговоренні, пропонуючи свої варіанти відповідей, коментарі й нові теми для обговорення.

Ресурс «Чат» призначений для організації дискусій у режимі реального часу (лекція та семінари). Користувачі системи мають можливість обмінюватися текстовими повідомленнями, доступними як усім учасникам дискусії, так і окремим учасникам на вибір.

Ресурс «Анкета» пропонує кілька типів анкет у курсі та використовується для оцінювання ефективності дистанційного навчання.

Pecypc SCORM/AICC - модуль, що надає можливість імпортувати пакети 3 набором об'єктів навчального призначення. Модуль SCORM/AICC дає можливість завантажувати будь-які стандарти пакетів SCORM або AICC, створені у зовнішніх системах, і робити їх частиною навчального курсу. Так наприклад, за допомогою LearningApps.org створено завдання «Знайти пару: давньоримський автор - прихильник республіки або імперії»: Гней Невій, Квінт Енній, Квінт Фабій Піктор, Марк Порцій Катон Старший і т.д.

Для одержання статистичних даних про навчальну діяльність здобувачів, а також для їх опрацювання 3 метою аналізу різних показників успішності з конкретної дисципліни, в системі електронного навчання на базі програмного продукту Moodle $\epsilon$ pecypc «Журнал оцінок $з$ дисципліни», структура якого містить категорії і підкатегорії. Журнал оцінок - це репозиторій, що містить оцінки за всі види навчальної діяльності здобувачів, передбачені структурою електронного навчального курсу. Перевагою платформи Moodle є модуль журналу «Оцінювання робіт». Так, виставляючи індивідуальну оцінку, платформа надає можливість залишити коментар, де можна аргументувати отриманий бал, і цей зворотній зв'язок бачить лише здобувач. Бал автоматично відправляється здобувачу на пошту й зараховується в журнал для під- рахунку підсумкової оцінки. Відповідно здобувачеві надана можливість в реальному часі бачити свій прогрес в отриманні балів упродовж навчального процесу.

Серед трьох форм проведення іспиту в дистанційному форматі, а саме: письмова, усна та тестова, була обрана перша. Однак, незалежно від форми, іспит проходив у синхронному режимі з процедурою ідентифікації осіб, що проходять іспит, записаною на відео. Для організації відеоспостереження за здобувачами вищої освіти, які проходять іспит, використовувалася система організації відеоконференцій GoogleHangouts Meet, яка доступна для всіх користувачів корпоративного домену, які мають поштову скриньку в цьому домені. Було проведено пробне тестування алгоритму проведення іспиту із завантаженням тестових білетів задля завчасного повідомлення про виникнення проблем та недоліків.

Здобувач відповідав на питання екзаменаційного білету в письмовому вигляді на заздалегідь підписаних аркушах паперу, робив фото своїх відповідей та додавав ці фото в якості відповіді на екзаменаційний білет. Крім того, час на виконання контрольного письмового завдання був суворо нормований, щоб студент не мав часу на пошук та використання інформації зі сторонніх джерел (Інтернет тощо).

Алгоритм проведення іспиту виглядав таким чином:

1) за 20 хвилин до початку екзамену і впродовж наступних 10 хвилин перший i другий викладач відкривали відеоконференцію у системі GoogleHangoutsMeet, яка заздалегідь була створена через GoogleCalendar. Здобувачi за запрошенням підключалися до неї;

2) після підключення до конференції студенти мали на листах для відповіді, підготовлених заздалегідь, зверху посередині підписати їх та увійти на ПДО Moodle;

3) Викладач проводить перекличку, в процесі якої студент входив до блоку екзаменування, підтверджував отримання білету, вимикав свій мікрофон, переписував білет та приступав до роботи;

4) за 10 хвилин до закінчення екзамену викладач оголошував про 10 хвилин, які залишились для відповіді на білет, і здо- 
бувачі мали змогу завершити за цей час оформлення своїх відповідей;

5) через 1 годину 30 хвилин від початку екзамену здобувачі мали зробити якісні фотографії своїх екзаменаційних робіт, відіслати їх на електронні пошти викладача i асистента/другого викладача (через звичайний поштовий клієнт на ПК або смартфоні) та завантажити їх в Moodle (користуючись відповідною формою під електронним білетом). Якщо під час відеоконференції зв'язок втрачався, то здобувач зобов'язаний був проінформувати викладача (телефон, електронна пошта) в індивідуальному порядку. Якщо відбувалися проблеми 3 прикріпленням звіту в Moodle, необхідно було у відведений час вислати відповідь на пошти викладачів; прикріпити їх в Moodle, як тільки з'являлася можливість (на відправку виділялися додаткові 15 хвилин);

6) після закінчення часу, виділеного на відправку відповіді, викладач оголошував про вихід здобувачів із Moodle-акаунтів, перевіряв вихід здобувачів із ПДО i прощався з групою у відеоконференції.

У випадках, коли іспит було перервано $з$ технічних причин, які не залежали від здобувача вищої освіти, він має право на повторне проходження іспиту. Для цього потрібно було зробити знімок екрана, який фіксував проблему в момент її виникнення та надіслати лист із темою повідомлення «Проблема при проходженні іспиту» на електронну адресу адміністратора впродовж 12 годин після закінчення іспиту. На його електронну адресу висилалося повідомлення про час повторного іспиту та пароль.

За результатами іспиту викладач формував електронну таблицю - звіт про проведення іспиту - та надсилав іiі чи електронну відомість у деканат.

Таким чином, карантин показав нестачу викладацьких компетенцій у кількох напрямах: цифрові навички, методична робота 3 цифровим контентом, онлайн-взаємодія в реальному часі. Методологія дистанційного навчання, формування цифрового навчального контенту, який виключає пряму взаємодію зі студентами, залишилася складною, відчувалася нестача знань й умінь $з$ педагогічного дизайну.

Таким чином, можемо зробити висновок, що вкрай потрібне подальше вивчення питання релевантної організації дистанційного навчання, оскільки виникає потреба переосмислити та реструктурувати весь навчальний процес, оновити зміст освітніх програм і розробити нові цілісні програми для дистанційного навчання, щоб доповнити мобільний вектор навчання, збагатити ангажованість студентів, а також уникнути факторів дезорганізації, відволікання від навчального процесу та втрати інтересу.

Необхідно провести більше досліджень відгуків студентів і викладачів, а також побажань щодо вдосконалення дистанційної освіти, оскільки вони є об'єктами та суб'єктами навчальної діяльності, які переживають період становлення дистанційного навчання на етапі його формування й раннього розвитку.

\section{ЛІТЕРАТУРА}

Концепція розвитку дистанційної освіти в Україні (затверджено Постановою МОН України В.Г. Кременем 20 грудня 2000 p.). URL: https://docs. google.com/viewer? $\mathrm{a}=\mathrm{v} \&$ pid $=$ sites\&srcid $=$ emFraW5 wc G8ub3JnLnVhfGRvfGd4OjU0Nzg0OTc5ZmU3OWJlY ZA (дата звернення: 20.02.2021).

Адамова I. 3., Головачук Т. I. Дистанційне навчання: сучасний погляд на переваги та проблеми // Вісник Чернівецького торговельно-економічного інституту. Витоки педагогічної майстерності. 2012. Вип. 10. С. 3-6.

Кухаренко В.М. Перешкоди впровадженню дистан-

ційного навчання // Дистанційна освіта: реалії та перспективи: матеріали 1-ї Всеукраїнської наук.-практ. конф., 12 грудня 2018 р. Харків, 2018.С. 35-38

Муковіз О. П. Основи організації дистанційного навчання у системі неперервної освіти: [методичні рекомендації]. Умань: ФОП Жовтий О. О.2016.66 с.

Радкевич В. О. Сучасні тенденції розвитку професійної освіти // Актуальні проблеми технологічної і професійної освіти. Матеріали Міжнародної науково-практичної конференції, 14 травня 2020 р. Глухів: Глухівський НПУ ім. О. Довженка. 2020.С. 60-66.

\section{REFERENCES}

Kontseptsiia rozvytku dystantsiinoio svity v Ukraini (zatverdzheno Postanovoiu MON Ukrainy V.H. Kremenem 20 hrudnia 2000 r.). [The concept of development of distance education in Ukraine (approved by the
Resolution of the Ministry of Education and Science of Ukraine VG Kremen on December 20, 2000)] docs.google.com. Retrieved from https://docs.google com/viewer? $\mathrm{a}=\mathrm{v} \& \mathrm{pid}=$ sites\& $\mathrm{srcid}=\mathrm{emFraW} 5 \mathrm{wcG} 8 \mathrm{ub} 3 \mathrm{~J}$ 
nLnVhfGRvfGd4OjU0Nzg0OTc5ZmU3OWJ1YzA $\quad$ [in Ukrainian].

Adamova, I. Z., Holovachuk, T. I. (2012). Dystantsiine navchannia: suchasnyi pohliad na perevahy ta problemy [Distance learning: a modern look at the benefits and challenges]. Visnyk Chernivetskoho torhovelno-ekonomichnoho instytutu. Vytoky pedahohichnoi maisternosti Bulletin of the Chernivtsi Trade and Economic Institute. The origins of pedagogical skills, 10, 3-6 [in Ukrainian].

Kukharenko, V.M. (2018). Pereshkody vprovadzhenniu dystantsiinoho navchannia [Obstacles to the introduction of distance learning]. Proceedings from Distance education: realities and prospects '18: I Vseukrainska naukovo-praktychna konferentsiia (12 hrudnia 2018 r.) The first all-Ukrainian scientific-practical conference (pp. 35-38). Kharkiv: KhNPUim. H. S. Skovorody [in Ukrainian].

Mukoviz, O. P. (2016). Osnovy orhanizatsii dystantsiinoho navchannia u systemi neperervnoi osvity [Fundamentals of distance learning in the system of continuing education]. Uman: FOP Zhovtyi O. O. [in Ukrainian].

Radkevych, V. O. (2020). Suchasni tendentsii rozvytku profesiinoi osvity [Current trends in vocational education]. Proceedings from Current issues of technological and vocational education '20: Mizhnarodna naukovopraktychna konferentsiia (14 travnia 2020 r.) - International scientific-practical conference (pp. 60-66). Hlukhiv: Hlukhivskyi NPU im. O. Dovzhenka [in Ukrainian].

Ніколаснко О. О.

доктор історичних наук, дочент, професор кафедри історії Украӥни Харківського національного педагогічного університету імені Г. С. Сковороди https://orcid.org/0000-0002-2294-4198

\section{КУЛЬТУРНО-ОСВІТНЯ ДІЯЛЬНІСТЬ ПОЛЬСЬКИХ ЖІНОК У МІСТАХ РОСІЙСЬКОЇ ІМПЕРІЇ НАПРИКІНЦІ ХІХ - НА ПОЧАТКУ ХХ СТ.}

Польські жінки традииійно відігравали важливу роль у підтримиі духовної культури громади. Особливо відчутною була їх роль у великих містах імперії - Москві, Києві, Петербурзі та Одесі, де зосереджувалась значна кількість польського населення. Мета даної статті полягає у виявленні характерних рис участі жіноцтва в культурному житті полонії міст. Для иььго використані методи індукиї, аналізу, історико-типологічний метод. На підставі аналізу архівних джерел та досліджень з даної тематики встановлені форми участі жінок в системі освіти польського населення, філантропічній діяльності, підтримиі начіональної культури - у розвитку театрального і музичного життя, розповсюдженні бібліотек тощо. Виявлено, що у всіх названих галузях жінки виявляли свої творчі здібності, організуючі різноманітні освітні заклади, громадські організаиії, мистецькі заходи.

Ключові слова: жінки, поляки, міста, Російська імперія.

Polish women have traditionally played an important role in supporting the spiritual culture of the community. Their role in the major cities of the empire - Moscow, Kiev, St. Petersburg and Odessa, where a large number of Polish population was concentrated - was especially significant. The purpose of this article is to identify the characteristics of women's participation in the cultural life of cities. For this purpose, methods of induction, comparative analysis, historical and typological method are used. On the basis of the analysis of archival sources and studies of this topic, the forms of women's participation in the polish population's education system, philanthropic activities, support of national culture - in the development of theatrical and musical life, distribution of libraries, etc. have been established. It was revealed that in all these areas women showed their creativity by organizing various educational institutions, social organizations and cultural events.

Keywords: women, Poles, cities, Russian Empire.

Важливу роль у житті польського населення міст Російської імперії відігравала культура. Духовна спадщина польського народу стала чинником інтеграції тих, хто жив далеко від батьківщини. В кінці XIX ст. у багатьох російських містах виникли організації, що підтримували національний театр, поширювали літературу, пропагували польську музику. Ці товариства дозволяли зберегти почуття національної єдності, згуртовуючи співвітчизників.

Величезне значення в підтримці національної культури належало польським жінкам. Однак їх імена не часто можна зустріти серед засновників або керівників культурних організацій, тому важко встано- 